\title{
Safety of non-woven polypropylene surgical adhesive drapes to prevent wound infection
}

\author{
A Jeurissen", R Hendrickx, K Beesemans, A Van Thielen, V Cossey, A Schuermans \\ From International Conference on Prevention \& Infection Control (ICPIC 2011) \\ Geneva, Switzerland. 29 June - 2 July 2011
}

\section{Introduction / objectives}

Wound infections caused by intra-operative contamination can be a major problem in surgery. The passage of bacteria through drapes is a potential source of wound infection. In this study we aimed to test the bacterial penetrability of 6 brands of non-woven polypropylene drapes.

\section{Methods}

Six brands of disposable non-woven polypropylene drapes were tested. A latex glove was used as a negative control and a woven cotton drape was used as a positive control. For each drape, a rodac plate was inoculated with $10^{5}$ colony-forming units / $\mathrm{ml}$ of Staphylococcus aureus ATCC strain 6538 and incubated at $37^{\circ} \mathrm{C}$ for $24 \mathrm{~h}$ to obtain confluent growth. Thereafter, each drape was placed between the incubated rodac plate and an inverted rodac plate with a weight of 400 gram placed thereon for 30 minutes. Subsequently, the inverted rodac plate was incubated for $24 \mathrm{~h}$ at $37^{\circ} \mathrm{C}$ and inspected for growth of S. aureus.

\section{Results}

The latex glove was totally impermeable, in contrast to the woven cotton drape which revealed heavy growth after 30 minutes. All the drapes made from non-woven polypropylene were impermeable.

\section{Conclusion}

Although bacterial penetration through surgical drapes can be time dependent, we here show that polypropylene non-woven drapes were impenetrable at 30 minutes. We therefore recommend the use of non-woven polypropylene drapes in surgical procedures

${ }^{1}$ Hospital hygiene and infection control, UzZ Gasthuiberg, Leuven, Belgium

\section{Disclosure of interest}

None declared.

Published: 29 June 2011

doi:10.1186/1753-6561-5-S6-P190

Cite this article as: Jeurissen et al:: Safety of non-woven polypropylene surgical adhesive drapes to prevent wound infection. BMC Proceedings 2011 5(Suppl 6):P190.
Submit your next manuscript to BioMed Central and take full advantage of:

- Convenient online submission

- Thorough peer review

- No space constraints or color figure charges

- Immediate publication on acceptance

- Inclusion in PubMed, CAS, Scopus and Google Scholar

- Research which is freely available for redistribution
() Bïmed Central

\section{Biomed Central}

C 2011 Jeurissen et al; licensee BioMed Central Ltd. This is an open access article distributed under the terms of the Creative Commons Attribution License (http://creativecommons.org/licenses/by/2.0), which permits unrestricted use, distribution, and reproduction in any medium, provided the original work is properly cited. 